Prace Historyczno-Archiwalne t. XXXIII, Rzeszów 2021

ISSN: 1231-3335

\author{
Krzysztof Śmiechowski \\ ORCID 0000-002-1487-7650 \\ DOI:10.30657/pha.33.2021.09 \\ (historyk, Rzeszów) \\ e-mail: ksm66@o2.pl
}

\title{
Ideologiczny fundament ukraińskiego Towarzystwa „Sokił” (1894-1914), cz. I: Cel, obowiązki, „przykazania”
}

\section{Streszczenie}

Powstałe w roku 1894 Ukraińskie Towarzystwo Gimnastyczno-Pożarnicze „Sokił” [Sokół] nie od razu zdobyło taką popularność, na jakiej zależało liderom organizacji. Początkowo zyskało uznanie jedynie w kręgach akademickich. Dopiero wtedy, gdy w pierwszej dekadzie XX w. rozwój organizacyjny nabrał szczególnej dynamiki, obejmując swoim zasięgiem znaczne obszary Galicji i pokonując przy tym wyboistą drogę wewnętrznego kształtowania - udało się trafić z przesłaniem do najniższych warstw społeczeństwa, budując oczekiwany autorytet.

Czas pokazał, że popularność „Sokiła” wynikała nie tyle z faktu, że była to organizacja gimnastyczno-pożarnicza, ale przede wszystkim z tego, że Towarzystwo wyrosło na prężną instytucję ukraińskiego życia narodowego. Pod szyldem gimnastyki i pożarnictwa ukraiński „Sokił” rozpoczął szeroko zakrojoną, wielokierunkową działalność manifestującą patriotyzm i tradycje narodowe oraz skrywającą ukryte głębiej cele niepodległościowe.

Z założenia, od chwili powstania, „Sokił” miał być organizacją hołdującą zasadom demokratycznym, Towarzystwem opartym na statucie, z Walnym Zgromadzeniem jako władzą najwyższą. 0 ile jednak statutowi, który w trakcie rozwoju organizacyjnego ulegał kilkakrotnym modyfikacjom, poświęcono należne miejsce w publikacjach dotyczących powstania i rozwoju Towarzystwa, to we wszelkich dotychczasowych opracowaniach dotyczących „Sokiła” w sposób marginalny traktowano aspekt ustrojowy i ideologiczny, w którym mieszczą się służące doktrynalnemu umacnianiu organizacji i wypracowane na jej użytek: prawa, normy, regulaminy, obowiązki, zasady członkowskie, ceremoniały, sokilskie umundurowanie, sztandar, hymn, hierarchiczne wyróżniki, organizacyjne odznaki czy hasła propagandowe.

Wraz z rozwojem organizacji i powstawaniem jej kolejnych filii, lwowska centrala „Sokił-Bat'ko” opracowywała szereg tego rodzaju wzorcowych dokumentów, tak by były one wspólne i typowe dla nowych ogniw Towarzystwa, gwarantując jedno- 
cześnie wszystkim gniazdom, rozsianym po całej Galicji, jednolity ustrój wewnętrzny. Ich redagowanie powierzono specjalnym komisjom. I choć sokilskie filie różniły się stopniem rozbudowania struktury organizacyjnej, to - dzięki wypracowanym teoretycznym podstawom - ustrojowo wykazywały jednorodność i integralność.

Dlatego w prezentacji cyklu artykułów dotyczących historii tego ukraińskiego Towarzystwa za stosowne uznano wyeksponowanie tego, mało znanego i pomijanego, aspektu jego działalności, co niewątpliwie stanowić może dopełnienie opracowanego tematu. Jednakże, ze względu na obfitość materiału, przedstawienie go w jednym artykule przekraczałoby wyznaczone periodykiem ramy objętościowe, stąd naturalnym był jego podział na kilka części, a pierwsza z nich to: Cel, obowiq̨zki, „przykazania”.

\section{Słowa kluczowe:}

Ukraińskie towarzystwo gimnastyczno-pożarnicze „Sokił”, Sokił, ukraińskie towarzystwo sportowe, Sicz, ideologiczny fundament ukraińskiego towarzystwa „Sokił”, cele sokiła, sokilskie normy, sokilskie przykazania.

W raz z wprowadzeniem autonomii Galicji i uzyskaniem przez mniejszości narodowe szeregu ustępstw ze strony monarchii austriackiej z końcem lat siedemdziesiątych XIX w. nastąpił wyraźny wzrost świadomości narodowej wśród mieszkańców. Możliwe stało się zakładanie towarzystw i organizacji, na co pozwalały ramy prawno-ustrojowe ówczesnego kraju koronnego.

Dość swobodny rozwój życia społecznego zaowocował tym, że już w roku 1886 działało we Lwowie 196 różnego typu polskich towarzystw i stowarzyszeń ${ }^{1}$. Obok zrzeszeń polskich zaczęły powstawać również towarzystwa żydowskie i ukraińskie. Oprócz oświatowych, ekonomicznych czy kulturalnych pojawiły się także pierwsze organizacje zajmujące się krzewieniem kultury fizycznej. Wśród nich najistotniejszą rolę zaczęło odgrywać Towarzystwo Gimnastyczne „Sokół”.

Po „Sokole” czeskim (1862) i słoweńskim $(1863)^{2}$, pierwsze polskie gniazdo powstało w 1867 r. we Lwowie. Wkrótce stało się ono kolebką całego polskiego ruchu sokolego w Galicji. Od roku 1884 tworzono kolejne ośrodki polskiego „Sokoła”, a w roku 1892 - przełomowym dla przyszłości sokolstwa ukraińskiego ${ }^{3}$ - było już 40 polskich towarzystw ${ }^{4}$.

Rozwój polskiego ruchu sokolego nie byłby może faktem dla Ukraińców niepokojącym, gdyby nie kwestia przyjmowania w ich szeregi również młodych Rusinów. A to już, w oczach postępowych ukraińskich działaczy, rodziło spore kontrowersje. Groziło to bowiem ukraińskiej mniejszości spolszczeniem, a tym samym potencjal-

J. Snopko, Polskie Towarzystwo Gimnastyczne „Sokół” w Galicji 1867-1914, Białystok 1997, s. 16.

2 A. Mirkiewicz, Zarys dziejów sokolstwa słowiańskiego (1862-1939), Rzeszów 2014, s. 35.

3 Momentem przełomowym, który ostatecznie zadecydował o założeniu ukraińskiego „Sokoła”, stał się zlot sokolstwa polskiego, który miał miejsce we Lwowie w dniach 5-6 czerwca $1892 \mathrm{r}$. Okazją było 25-lecie utworzenia pierwszego gniazda na ziemiach polskich. A. Mirkiewicz, Zarys dziejów sokolstwa..., s. 92; s. M. Hubczak, Spomyny pro naszoho „Sokoła”, [w:] Sokił-Bat'ko. Sportywno-Ruchankowe Towarystwo u Lwowi. Almanach 1894-1994, Lwiw 1996, s. 190.

4 J. Snopko, Polskie Towarzystwo Gimnastyczne..., s. 74. 
nym wynarodowieniem ${ }^{5}$. Szczególnie widoczne stawało się to na prowincji, gdzie tego typu stowarzyszenia oferowały często jedyną możliwość przyjemnego i kulturalnego spędzenia wolnego czasu, kusząc przy tym niezdecydowanych bogatą ofertą imprez pozasportowych. A trzeba tu pamiętać, że towarzystwa sokole, oprócz propagowania kultury fizycznej i higieny, posiadały szerszą ofertę programową, prowadząc koła teatralne, chóry, orkiestry, czytelnie czy organizując m.in.: szkolenia przeciwpożarowe, wieczorki, koncerty, bale, odczyty i różnorakie kursy. W związku z tym, postępowa część ukraińskiej inteligencji poczęła także poszukiwać nowych form organizacyjnych dla tej społeczności, próbując najpopularniejsze z istniejących ówcześnie systemów adaptować do własnych potrzeb. Ukraińcy, głównie z inicjatywy „Proswity”, zaczęli zakładać narodowe instytucje oświatowe, kulturalne i ekonomiczne. W obszarze krzewienia kultury fizycznej nie mogli jednak opierać się na własnych wzorcach, dlatego skorzystali w tym celu z doświadczeń czeskich i polskich, zwracając się ku sokolstwu.

Za oficjalną datę powstania ukraińskiego Towarzystwa Gimnastycznego „Sokił” nie przyjmuje się ani 17 lipca 1892 r. - dnia, w którym odbyło się zebranie przygotowawcze, przyjmujące statut i nazwę przyszłego towarzystwa, ani też daty oficjalnego zatwierdzenia statutu przez władze - 26 lipca 1893 r., ale dzień 11 lutego 1894 r. Wtedy to we Lwowie, w siedzibie „Ruśkoji Besidy” przy ulicy Ormiańskiej 2, w kamienicy naprzeciwko Domu Narodowego, odbyło się I Walne Zebranie członków Ruskiego Towarzystwa Gimnastycznego „Sokił”.

W zamyśle założycieli nowego stowarzyszenia, miało ono w niedługim czasie stanąć w jednym szeregu obok tak istotnych dla społeczeństwa ukraińskiego organizacji, jak wspomniana „Proswita”, „Narodna Torhiwla”, „Ridna Szkoła” czy towarzystwo ubezpieczeniowe „Dnister”.

Od samego początku przyjęto w „Sokile” za jeden z podstawowych celów szeroko rozumianą działalność na rzecz ojczyzny i narodu. Zamiarem założycieli „Sokiła” było utworzenie takiej ogólnonarodowej organizacji, która zdolna byłaby poprowadzić wielokierunkową działalność, służącą interesom społeczeństwa i przyszłej niepodległej Ukrainy. Budując struktury, zakładano zorganizowanie narodu, zjednocze-

5 O.M. Hudołyj, S.M. Fyl, G.W. Małka, Istorija fizycznoji kultury (Nawczalnyj posibnyk), Charkiw 2003, s. 105.

6 Centralnyj Derżawnyj Istorycznyj Archiw Ukrajiny m. Lwiw [dalej: CDIAUL], F. 312, op. I, spr. 37, Księga protokołów 1894-1902, s. 1-2.

7 Wśród założycieli ukraińskiego towarzystwa „Sokił” należy wymienić przede wszystkim dwie postaci: Wołodymyra Ławriwśkiego i Wasyla Nahirnego. Wołodymyr Ławriwśki (ok. 1850 - zm. 14 VII 1936) był synem działacza społecznego z lat sześćdziesiątych XIX w. Pełnił funkcję komisarza starostwa. Jako gorący orędownik sokilskiej idei, stał się jednym z założycieli Towarzystwa, a także twórcą pierwszego statutu „Ruskiego Sokiła” - jak wówczas je nazywano. Ławriwśki był także autorem i wydawcą publikacji: Kałendar "Sokił" na rik 1895. W latach 1894-1897, zasiadając w zarządzie Towarzystwa, sprawował funkcję administratora. Wasyl Nahirnyj (1848-1921), był wybitnym architektem, budowniczym ukraińskich obiektów, działaczem społecznym, założycielem towarzystw: „Narodna Torhiwla”, „Dnister”, „Narodna Hostynnycia”, „Trud”, przewodniczącym rzemieślniczego towarzystwa „Zoria”, właścicielem i redaktorem popularnego dwutygodnika „Bat'kiwszczyna”, autorem wielu artykułów aktywizujących życie polityczne narodu ukraińskiego. Jako współtwórca ukraińskiego towarzystwa „Sokił', został jego pierwszym prezesem i sprawował tę funkcję w latach 1894-1900. Wybrany na kolejną kadencję w roku 1901, zrzekł się stanowiska. 
nie go wokół wspólnej sprawy, wdrożenie do karności, pracowitości i przekonanie do pielęgnowania wspólnych, fundamentalnych wartości, gdyż w pojęciu sokilskim jednostka znaczyła niewiele. Liczył się tylko naród, mający własną świadomość, własną tożsamość, żyjący w niepodległym, silnym i dobrze zorganizowanym państwie.

Towarzystwo „Sokił” miało aspiracje podejmowania pracy u podstaw dla stworzenia takiej wspólnoty wśród nieuświadomionych jeszcze jednostek. Chodziło przy tym o to, aby ludzi tych odpowiednio przygotować, wykształcić, usprawnić fizycznie, wychować patriotycznie, zahartować do pracy i nauczyć przezwyciężać wszelkie życiowe trudności. W realizacji założeń programowych twórcom sokilstwa przyświecała starogrecka kalokagatia [gr. kalokagathia - „piękny i dobry”], której antyczne wartości zamierzano w jakiejś mierze przetransponować. Przyjęło się przekonanie, że rozwój duchowy jest nierozerwalnie związany z rozwojem fizycznym. Od wieków wszak znane było hasło: „W zdrowym ciele zdrowy duch”, stąd w organizacji wychowawczej, jaką miał być „Sokił”, nie można było idei tej pominąć.

Czerpano także z doświadczeń i pomysłów Miroslava Tyrša - twórcy sokolstwa - zalecającego uwzględnianie w programie narodowotwórczym takich wartości, jak: braterstwo, sprawiedliwość, prawda.

Sokilskie wychowanie przesycono duchem patriotyzmu, który miał stać się źródłem narodowej siły. Organizacja wychowywała swoich członków nie po to, by zamykali się sami w sobie czy istnieli dla siebie, ale po to, by służyli własnej nacji. W „Sokile” przechodziło się szkołę niezłomności charakteru i tężyzny fizycznej. „Sokiłem” - głoszono - nie był ten, kto należał do Towarzystwa, ale ten, kto nim był na ulicy, w rodzinie, w pracy zawodowej, zawsze - co ważne - w pracy na rzecz środowiska. Kto zatem chciał zasługiwać na miano ukraińskiego „sokiła”, ten musiał ćwiczyć ciało i przyswajać sobie przymioty wzorowego obywatela ${ }^{8}$. „Sokiłem” był ten, kto sokilskie idee potrafił wdrażać w życie, kto umiał postępować jak „sokił”. Kto uczciwie, z oddaniem i wiernie służył ojczyźnie. „Sokił” musiał się wyróżniać zarówno pod względem zewnętrznym, jak i wewnętrznym. Dlatego od członków wymagano, aby prezentowali sprężystą postawę, pogodne oblicze, pełnię cielesnego rozwoju i nosili sokilskie umundurowanie.

Z przymiotów wewnętrznych starano się wpoić członkom: uczciwość, rycerskość, odwagę, równowagę duchową, ofiarność w działaniach społecznych, pracę na rzecz swojej organizacji i pracowitość w ogóle, dokładność w wykonywaniu swoich obowiązków, karność i posłuszeństwo, porządek, poświęcenie, sprawiedliwość, wytrwałość, męstwo, zaradność, zdecydowanie, umiejętność panowania nad sobą, umiarkowanie, dyskrecję, radość życia, skromność, szczerość, spokój, czystość, oszczędność, spostrzegawczość, inicjatywę i przedsiębiorczość ${ }^{9}$. Pisano m.in.:

[...] Sikawka i trąba w przypadku pożarniczych towarzystw to jeszcze nie „Sokił” ani „Sicz"10. A chociażby prowadziły [towarzystwa] pięknie ćwiczenia i organizowały

8 Zob. „Sokilśki Wisty”, nr 6, czerwiec 1937, s. 1.

9 Zob. Sokilśky Czesnoty [w:] Sokilśkyj Kałendarec 1938, Lwiw 1937, s. 89.

10 Chodzi tu o nowo powstające filie Towarzystwa "Sokił”, którym po Kongresie „Proswity” w roku 1909 pozwolono, w oparciu o statuty „Sokiła”, przyjmować nazwę „Sicz”. W sposób stanowczy sprzeciwiali się temu liderzy „Siczy” radykalnych z Kyryłem Trylowśkim na czele, odcinając się od nich i nazywając je pogardliwie „pałamarskimi” [od słowa pałamar oznaczającego posługacza cerkiewnego lub dzwonnika]. K. Śmiechowski, $Z$ „Sokiłem” $w$ tle. Powstanie i rozwój ukraińskich organizacji gimnastyczno-pożarniczych „Sicz” (1900-1914), „Prace Historyczno-Archiwalne” 2020, t. XXXII, s. 88-89. 
pochody, to jeszcze nie sokilska i siczowa idea. Nasze sokoły i sicze powinny działać na wzór starożytnych Spartan - utworzyć swego rodzaju spartańska szkołę dla naszego narodu i w tym upatrujemy ich działalności ${ }^{11}$.

Łatwo zauważyć, że sokilstwo podporządkowywało osobiste korzyści jednostki interesowi odrodzenia narodowego. Zgodnie z wyznawanym przekonaniem, odrodzenie miało być „pięciotorowe”: fizyczne, moralne, postępowe, demokratyczne i narodowe. Tych pięć założeń, stopionych w całość, tworzyło sokilską ideę i sokilski szlak.

W organizacji uczono: honoru, słowności, systematyczności, zamiłowania do pracy, dokładności w wykonywaniu każdego zadania.

Towarzystwo, jako organizacja dobrowolna, działało - oprócz statutu - także w oparciu o własne przepisy i normy. W tym celu wypracowano szereg reguł i zasad postępowania, których należało przestrzegać.

Pozostając w łączności z ruchem słowiańskim, jako znak Towarzystwa przyjęto sokoła - ptaka wolności. Niektórzy dostrzegali stylizowany wizerunek sokoła nawet w narodowym herbie Ukrainy - Tryzubie, który przypominał im pikującego, uderzającego z góry sokoła ze złożonymi skrzydłami ${ }^{12}$. Sokół wskazywał na to, że członkiem organizacji mógł zostać tylko ten, kto - pomimo życia pod zaborami - chciał być wolnym człowiekiem. Wolnym duchowo, pozbawionym wad i nawyków, które czyniły z niego niewolnika. Członkostwo zobowiązywało do tego, by jak sokół wznosić się w górę, ponad wszystkich, by scalać siły ciała i ducha i sposobić je do decydującego uderzenia. Przynależność do Towarzystwa uważana była za honor dla jednostki: [...] Nazywamy siebie Sokołami, bo chcemy być wolni i swobodni jak sokił, który wysoko i swobodnie lata nad ziemią. O młodzieńcach-sokołach sprawnych z bystrym wzrokiem śpiewał już nasz ukraiński naród w swoich starych narodowych pieśniach. Sokił w naszej ukraińskiej pieśni to symbol swobody, męskości i życia ${ }^{13}$.

Za nadrzędne obowiązki „sokiła” uważano: wierność Bogu i religii, Ojczyźnie i narodowi, wypełnianie obowiązków wobec własnej organizacji, wobec członków towarzystwa i w końcu także wierność sobie samemu. Ujęte w pięciu grupach, przedstawiały się następująco:

I. Obowiązki wobec Boga i religii - „Sokił” jako organizacja narodowa przywiązywał wagę do wartości moralnych, wymagając od swoich członków m.in. szacunku dla Boga i Cerkwi. Nie godzono się na gorszące rozmowy i wygłaszanie poglądów mogących godności Cerkwi uwłaczać.

II. Obowiązki wobec Ojczyzny i narodu - „Sokił” miał zapisaną obowiązkową miłość do Ojczyzny. Miała się ona wyrażać przede wszystkim w wyrzeczeniach i poświęceniu w służbie na rzecz kraju. Członkowie, uważający Ojczyznę za najwyższą wartość, mieli pragnąć dla niej największego dobra. W obronie jej wolności i honoru powinni być zdolni do największych poświęceń. Do tej grupy obowiązków zaliczano poznanie historii narodu, jego kultury i tradycji. Od członków wymagano, by zawsze przyznawali się do swego pochodzenia, by byli z niego dumni, by szanowali język

11 Zob. „Sokilśki Wisty”, nr 1, 3 września 1908, s. 1.

12 W symbolice Tryzuba, oprócz wizerunku sokoła, dopatrywano się także dojrzałego kłosa zboża lub stylizowanego napisu „WOLA” (Wolność).

13 Poradnyk dla pożarno-ruchankowych towarystw "Sokił”, zładyła na pidstawi praci Semena Horuka „Na sokołynych kryłach” orh. sekcija „Sokiła-Bat'ka”, Lwiw 1926, s. 78, „Narodne Słowo” 1910, nr 361, dodatek: „Wisty z Zaporoża”, nr 18 z 12 maja 1910, s. 14. 
ukraiński jako znak zewnętrzny swojej narodowości. Oczekiwano również od nich, by byli aktywnymi propagatorami fizycznego, duchowego i ekonomicznego odrodzenia narodu w każdym przejawie jego życia.

III. Obowiązki wobec swojej organizacji - w tej grupie obowiązków wymagano:

- dbania o honor i rozwój organizacji [w tym zawierał się szacunek dla sokilskiego stroju i odznak], a także szacunku dla przełożonych;

- własnej pracy na rzecz organizacji;

- szacunku dla postanowień kierownictwa [członkowie mieli działać zgodnie ze statutem];

- poszanowania dla majątku organizacji;

- obowiązku pomnażania jej dobra;

- dobrej znajomości własnej organizacji, jej celu, idei, historii, stopni organizacyjnych;

- daty powstania organizacji i swojej filii, znajomości starszyzny własnego gniazda, sokilskich odznaczeń i odznak hierarchicznych;

- karnego wypełniania nakazów towarzystwa.

Tutaj warto wspomnieć, że organizacja utrzymywała ustalony porządek i ścisły układ hierarchiczny: [...] Każdy członek wstępujący do „Sokiła” dobrowolnie zobowiązuje się do posłuchu i karności. Nieposłuszeństwa i niesubordynacji nie śmie być w sokołach. Musimy się nauczyć słuchać rozkazów. W naszej organizacji nie ma próśb. Wychodzi rozkaz od starszyzny i każdy jest zobowiązany go słuchać ${ }^{14}$.

IV. Obowiązki wobec członków organizacji - obowiązkiem każdego „sokiła” było uważanie współczłonków za braci i siostry, zwanych odpowiednio „pobratym” i „posestra”, i pozdrawianie się słowem „Harazd” [zgoda].

V. Obowiązki wobec siebie samego - w tym obszarze wymagano od członków dbałości o honor własny, sumienne wypełnianie sokilskich i zawodowych obowiązków, niedopuszczanie do sytuacji, w której mogłoby dojść do zniewagi osobistej, stronienia od czynów mogących splamić honor organizacji, przyswojenia sobie sokilskich przykazań i poznania ich znaczenia ${ }^{15}$.

Ale to nie wszystko, czego wymagano od członków Towarzystwa. 0 szerokim spektrum obowiązków pisano tak: [...] My Sokoły mamy dbać o życie i o ruch, o świadomość i bezustanna pracę dla dzieci naszego chłopskiego narodu niewolników. Na nas zwrócona jest uwaga całego społeczeństwa. Dla nas nie ma odpoczynku. My Sokoły musimy iść w pierwszym rzędzie walczących o prawdę i wolność. Do nas należy nawoływać naród, by powstał, by zabrał się do dzieła i by okrzyk wolności gromem przetoczył się od kraju do kraju naszej Ojczyzny. Gdzie jest Sokił, tam powinna być także i ukraińska szkoła. Biedę zmniejszymy, gdy nikt ze wsi nie pójdzie kupować do wroga, kiedy nikt nie pójdzie do obcego, a tylko do swojego sklepu. Zakładajcie ukraińskie sklepy i kupujcie u swoich. Zakładajcie kasy i wszelakie spółki i w spółki się łączcie. Przy Sokile albo przy Proświcie zakładajcie biblioteki i czytajcie co można. Niechaj chata Sokiła, niech sokilska pożarnia [remiza strażacka] nie stanie się tylko miejscem dla sokiłów, ale miejscem dla wszystkich ${ }^{16}$. [...] Dom Sokiła niech stanie się źródłem pomocy, porady, nauki

14 „Wisty z Zaporoża”, nr 80 z 30 kwietnia 1913, s. 2.

15 E. Żarski, Osnowy Sokilstwa, Lwiw 1937, s. 9-24.

16 Zob. „Sokilśki Wisty”, nr 17, 25 grudnia 1908, s. 1. 
i ośrodkiem narodowego życia na wsi. Kiedy to się stanie, nie spostrzeżecie nawet, kiedy ciężkie kajdany niewoli spadna z nóg waszych, a słońce wolności i prawdy zaświeci ${ }^{17}$.

Oprócz obowiązków, dla członków opracowano zasady, które znalazły odzwierciedlenie w „dziesięciu przykazaniach” ukraińskiego „Sokiła", stając się tym samym ideologicznym fundamentem organizacji. Zamieszczono ich tekst na legitymacji członkowskiej, by wskazywały, niczym latarnia morska, właściwą drogę postępowania każdemu, kto

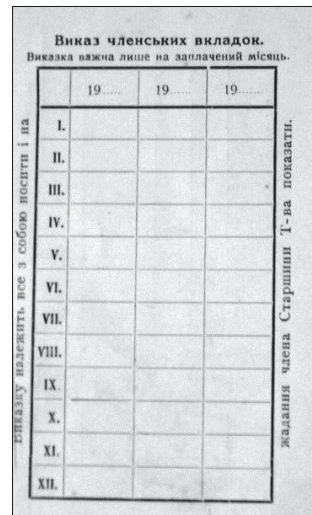
Десять заповідей украг̆нськог "Сокопа" (-ки):

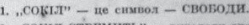

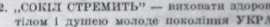

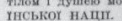

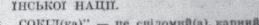

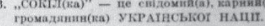

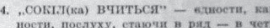

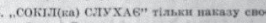

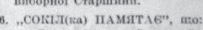

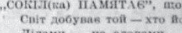

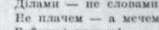
Bañzysai ruirgm!
Нероба сras paбom. Hо лебедіти - але етреміти

7. „СокII(ка) ДвАє" про:

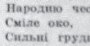
Masto cris,

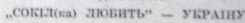

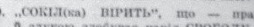

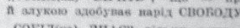

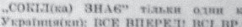

Wewnętrzna strona sokilskiej legitymacji z tekstem „przykazań”. Źródło: CDIAUL, F. 312, op. I, spr. 18. po nią sięgnie:

1. „Sokił”(ka) to symbol swobody,

2. „Sokił”(ka) dąży do wychowania zdrowego na ciele i duszy młodego pokolenia ukraińskiego narodu,

3. „Sokił”(ka) jest świadomym, karnym obywatelem ukraińskiego narodu,

4. „Sokił”(ka) uczy się jedności, karności, posłuszeństwa, stania w szeregu,

5. „Sokił”(ka) słucha tylko rozkazu swojej wybornej starszyzny,

6. „Sokił”(ka) pamięta, że: świat posiada ten, kto go zdobywa, czynami - nie słowami, nie płaczem, a mieczem! Obojętni - giną! Leń - zostaje niewolnikiem! Nie czekać, a działać,

7. „Sokił”(ka) dba o: honor narodu; śmiałe oko; silną pierś; jest przekonany, że czyny znaczą więcej niż słowa,

8. „Sokił”(ka) kocha Ukrainę,

9. „Sokił”(ka) wierzy, że pracą i zjednoczeniem naród zdobywa wolność,

10. „Sokił”(ka) zna tylko jedno hasło Ukraińca(ki): „Wszyscy naprzód! Wszyscy razem!"18.

Oprócz powyższych przykazań, obejmował każdego „sokiła” także pakiet zobowiązań wobec własnego gniazda. Zaliczano do nich:

- znajomość historii Towarzystwa, własnego gniazda, jego statutu (najważniejszych postanowień) i obowiązujących regulaminów,

- znajomość składu starszyzny swojego gniazda,

- karne słuchanie i wykonywanie poleceń i nakazów własnej starszyzny,

- sumienne uczęszczanie na ćwiczenia fizyczne i przygotowywanie [ci, których to dotyczyło] miesięcznych lub tygodniowych sprawozdań z życia gniazda,

- sumienne płacenie składek,

- prenumerowanie sokilskiej prasy i wydawnictw,

- dbanie o przepisowy strój sportowy,

17 Zob. „Narodne Słowo” 1910, nr 420, dodatek: „Wisty z Zaporoża”, nr 45 z 29 września 1910, s. 18.

18 CDIAUL, F. 312, op. I, spr. 18 [blankiet legitymacji członkowskiej]. 
- branie udziału w zmaganiach, ćwiczeniach i imprezach organizowanych przez własne gniazdo,

- pracę dla dobra swojego gniazda,

- werbunek nowych członków,

- znajomość sokilskich odznaczeń,

- branie czynnego udziału w życiu społecznym ${ }^{19}$.

Osobnymi zasadami były te dotyczące bezpośrednio wychowania fizycznego. Wynikało z nich, że Towarzystwo Gimnastyczne „Sokił”:

- formuje ciało dziecka, młodzieńca i dziewczyny;

- zapewnia pomoc w pełnym rozwoju wszystkich funkcji w granicach naturalnych zdolności;

- zabezpiecza największe bogactwo człowieka: zdrowie - tak, by każdy mógł się stać wytrwałym i niestrudzonym pracownikiem;

- dąży do tego, by każda jednostka jak najdłużej w życiu angażowała swe siły na rzecz propagowania przyjętej idei ${ }^{20}$.

Sokilstwo próbowano na swój sposób zdefiniować, określając je jako: społeczna szkołę narodu, która miała nauczyć jednostki stać na straży narodowych interesów lub jako: długoletniq praktyczną szkołę narodowo-społecznego współżycia w jego najrozmaitszych przejawach ${ }^{21}$. Choć uważano je za szkołę, to przyjęcie i przynależność do niej wymagały spełnienia pewnych warunków.

Przyjmowanie nowych członków było w Towarzystwie wydarzeniem eksponowanym. Chociaż trzeba zauważyć, że w pierwszych latach istnienia organizacji oraz w czasach kryzysu wewnętrznego, przypadającego na lata 1897-1900, kiedy szczególnie zabiegano o nowych członków, nie nadawano ich przyjęciu specjalnego rozgłosu. Odbywało się to niejako rutynowo, zwyczajnie. Stopniowo ceremoniał przyjmowania w szeregi „Sokiła” urósł do rangi znaczącego wydarzenia, połączonego z uroczystą przysięgą. Z czasem kandydatów na członków zaczęto poddawać szkoleniu ideologicznemu i sześciomiesięcznemu okresowi próbnemu ${ }^{22}$. Wspomniany kurs ideologiczny bywał zwykle trzystopniowy. Niższy, albo początkowy, był obowiązkowy dla wszystkich wstępujących do Towarzystwa, średni - przeznaczony dla wychowawców sokilskich gniazd oraz wyższy - dla odpowiedzialnych sokilskich pracowników najwyższych szczebli organizacji związkowej. Na zakończenie kursu niższego stopnia urządzano zawsze wymianę myśli i poglądów na temat zadań ukraińskiego sokilstwa w ogóle, albo też własnego Towarzystwa, z uwzględnieniem specyficznych dla danej miejscowości warunków. Aby przystąpić do szkolenia i okresu próbnego, kandydaci musieli najpierw zdobyć pozytywną rekomendację przynajmniej dwóch członków organizacji. Dopiero wtedy, w pełni świadomie, znając swoje obowiązki, mogli przystąpić do złożenia uroczystej przysięgi. Ceremoniał ten rozpoczynało zwykle wejście pocztu sztandarowego i przedstawicieli zarządu. Przy tej okazji przy-

19 E. Żarski, Osnowy..., s. 24-25.

20 Zob. „Sokilśki Wisty”, nr 12, grudzień 1937, s. 1.

21 Zob. „Ukrajinśkyj Sokił”, Czasopys Sojuzu Ukrajinśkoho Sokilstwa za Kordonom, nr 4-5, kwiecień-maj 1935, s. 2.

22 CDIAUL, F. 312, op. I, spr. 78, ark. 44. 
pominano przyjmowanym o ich przyszłych obowiązkach wobec sokilskiej rodziny. Nakreślano także cel i zadania Towarzystwa. Następnie przedstawiciel zarządu odczytywał treść przysięgi:

„Przyrzekam dla dobra Narodu Ukraińskiego uczciwie i sumiennie wykonywać swoje obowiq̨zki wobec ukraińskiego sokilstwa i być posłusznym wszystkim nakazom sokilskiej starszyzny - Harazd!"23.

Lub, jak w gniazdach emigracyjnych:

„Swoim honorem i uczciwościq obiecuję dobrowolnie poddać się sokilskiej karności, honorowym postępowaniem $i$ wytrwała praca dążyć do rozwoju narodowego ojczystego sokilstwa. Z własnej woli uroczyście obiecuję zawsze i wszędzie szanować wysokie sokilskie władze i bez zastrzeżeń poddać się nakazom swojej starszyzny dla dobra sokilskiej idei i całego Narodu Ukraińskiego. Znam zadania i cele ukraińskiego sokilstwa, jakie będę wykonywać ze wszystkich sił z jedynym pragnieniem, aby nasza Ojczyzna jak najszybciej stała się wolnq, niepodległa Ukrainq"24.

Po odczytaniu treści przysięgi, administrator gniazda wyczytywał kolejno wszystkich nowo wstępujących członków z imienia i nazwiska, a oni, podchodząc do sztandaru, jedną rękę kładli na nim, a drugą unosząc w górę, wygłaszali uroczyście formułę: „Obiecuję". Po złożeniu przysięgi prezes gniazda lub osoba go zastępująca wznosiła okrzyk z sokilskim hasłem: „Wse Wpered, Wsi Wraz!”. Oficjalną część uroczystości kończyły zwykle pokazy fizycznej sprawności członków „Sokiła”. Po nich następowała część nieoficjalna, najczęściej z tańcami i zabawami, które kończyły uroczysty wieczór.

Z czasem ideolodzy sokilscy poszli dalej. Oprócz praw, obowiązków i norm postępowania określili zbiór pewnych zachowań w najrozmaitszych przejawach życia. Nie miały one wprawdzie charakteru imperatywnego, ale zalecano wdrażać je w życie i naśladować. Stanowiły zespół norm sokilskiego savoir-vivre’u. Opracował je Semen Horuk i zamieścił w wydanym w 1911 r. poradniku pt. Na sokołynych kryłach [Na sokolich skrzydłach]. Jego fragmenty publikowano w sokilskich kalendarzach.

Dość istotnym problemem dla kierownictwa Towarzystwa było opanowanie zjawiska, określanego jako „grupowo-partyjny rozbrat”. Do towarzystwa przyjmowano bowiem wszystkich: „prawych” i „lewych”, bezpartyjnych, prawosławnych, katolików i niewierzących, jednocześnie wymagając od nich, by szanując swoje poglądy partyjne czy religijne, szanowali poglądy innych. Wymagano i surowo przestrzegano, aby: "Sokił” stał poza wszelkimi partiami i partyjnymi tarciami, by „Sokit” nie śmiał się stać terenem partyjnej walki, a każdy [z członków] wyrobił sobie takie polityczne przekonanie, które nie byłoby sprzeczne z sokilskimi ideami. Na terenie „Sokiła” jest on [członek] tylko „Sokiłem” i Ukraińcem i niczym więcej. Na drodze do osiagnięcia celów musi znaleźć wspólna płaszczyznę porozumień. Na forum Towarzystwa wyklucza się także wszelkie religijne tarcia. Niedopuszczalnym jest, by „Sokił” został terenem antyreligijnej propagandy ${ }^{25}$. Chociaż uznawano wielkie znaczenie Cerkwi, starano się jednocześnie dystansować od przekonań religijnych poszczególnych członków. Kładziono nacisk, by Towarzystwo stanowiło jedną wielką rodzinę, w której relacje między członkami cechować miały braterska miłość, wzajemny szacunek i pokładanie wiary jednych w drugich. Służyć temu miały m.in. stosowane formy zwrotne.

${ }^{23}$ CDIAUL, F. 312, op. I, spr. 9.

24 CDIAUL, F. 312, op. I, spr. 109.

25 CDIAUL, F. 312, op. I, spr. 9. 
Od wprowadzenia w życie idei M. Tyrša, założyciela sokolstwa, przyjęto postanowienie, że wszyscy członkowie tej organizacji, ze względu na deklarowaną równość, będą się do siebie zwracać „per ty”. Postanowienie to, początkowo przyjęte z nieufnością, stało się z czasem zwyczajem w sokolej rodzinie. Czesi, wówczas słabo zorganizowani, mało świadomi własnej odrębności, zaczęli dostrzegać w tej formie zwrotnej nie tylko wychowawczy moment swojego postanowienia, ale uważali ją za jedną z dróg do zjednoczenia sił sokolstwa, a przez „Sokoła” - siły narodu. Źródeł takiego postępowania należy doszukiwać się w demokratycznych założeniach tej organizacji, która, nakazywała każdemu uważać wszystkich za równych sobie i, jak równy z równym, zwracać się do siebie przez „ty”. Podobna zasada została przyjęta w organizacjach sokolich pozostałych narodów słowiańskich; przynajmniej teoretycznie.

Z historii polskiego „Sokoła” wiadomo, że zdarzało się, iż w niektórych Towarzystwach, choć w założeniach mających tworzyć strukturę pozaklasową, nie do końca zrozumiano tę regułę. Bywały przypadki lekceważenia „sokołów” rzemieślników przez „sokołów” wywodzących się z inteligencji. Czy, jak w Krośnie, gdzie dyrektorzy, członkowie „Sokoła”, wyprosili z zabawy „sokoła” - magazyniera ${ }^{26}$. Przypadki te, nienależące do rzadkości w początkowym zwłaszcza okresie istnienia organizacji, były dalekie od zakładanego zacierania różnic klasowych.

Dlatego też z wielką ostrożnością podchodzono do zagadnienia wzajemnego bratania się w „Sokile” ukraińskim. Zwracano przy tym uwagę na nienadużywanie tego rodzaju formy zwrotnej, podkreślając jednocześnie, że zawarty w niej musi być głęboki szacunek. Pierwotnie, w pierwszym roku działalności Towarzystwa, na wniosek członka zarządu, Wołodymyra Ławriwśkiego, 7 listopada 1894 r. przyjęto jako formę grzecznościową w kontaktach między członkami zwrot: „Druh”. Od tej pory, członkowie Towarzystwa tak mieli się do siebie zwracać, a pozdrawiać słowem: „Zdrów”27. Z czasem zastąpiono druha formami: „Pobratym” i „Posestra”. W roku 1902, na wniosek prezesa Alfreda Budzynowśkiego, do powszechnego użytku, obok okrzyku: „Bodrimsia!” [ukr. krzepmy się; budźmy się - odpowiednik polskiego „Czuwaj!”] wprowadzono sokilskie pozdrowienie: „Harazd”, co znaczyło „Zgoda”28. Miało to być odejściem od utartych społecznie tytułów, jak: „pan”, „dobrodziej” czy „mecenas”. W swym wydźwięku pobratym i posestra musiały być wykładnikiem najwyższego uznania wobec innych, na czym planowano zbudować organizacyjne współżycie oparte na zasadach braterstwa ${ }^{29}:$ [...] W Sokile my jesteśmy pobratymcami i posestrami. Jako pełnoprawni członkowie jesteśmy sobie równi. Mamy nie tylko prawa, ale i obowiązki. Może być tak, że ludzie między soba są równi, ale pomiędzy nimi żadnego braterstwa nie będzie ${ }^{30}$. [...] W Sokile zanikają wszelkie różnice społeczne. Zostaja tylko pobratymcy i posestry zjednoczeni we wspólnej myśli i wspólnym celu. Bez tego nie może być mowy o właściwej pracy i płynnym życiu sokiłów ${ }^{31}$.

Członkom Towarzystwa zabraniano przynależności do innych organizacji, a to z tego powodu, że organizacje te, w większości należące do radykałów, jak np. „Sicz”,

26 J. Snopko, Polskie Towarzystwo Gimnastyczne..., s. 113.

27 CDIAUL, F. 312, op. I, spr. 37, Księga protokołów 1894-1902, Protokół Walnego Zebrania Członków Towarzystwa Gimnastycznego „Sokił” z dnia 7 listopada 1894 r., s. 33.

28 CDIAUL, F. 312, op. I, spr. 38.

${ }^{29}$ CDIAUL, F. 312, op. I, spr. 9.

30 Zob. „Sokilśki Wisty”, nr 1, styczeń-luty 1933, s. 4.

31 CDIAUL, F. 312, op. I, spr. 9. 
były partyjnymi przybudówkami. Jako takie, były przesiąknięte ideologią partyjną, stojąc tym samym w sprzeczności z apolitycznością „Sokiła”. Wyjątek zrobiono tylko w przypadku przynależności do Towarzystwa „Proswita”.

Wreszcie, jednym z ostatnich i najważniejszych zarazem obowiązków członka Ukraińskiego Towarzystwa Gimnastycznego „Sokił” było posiadanie sokilskiego munduru.

\section{Bibliografia}

\section{Źródła archiwalne:}

Centralnyj Derżawnyj Istorycznyj Archiw Ukrajiny m. Lwiw (CDIAUL), zespoły:

Fond 312, op. I, spr. 9.

Fond 312, op. I, spr. 18.

Fond 312, op. I, spr. 37 (Księga protokołów 1894-1902).

Fond 312, op. I, spr. 38.

Fond 312, op. I, spr. 78, ark. 44.

Fond 312, op. I, spr. 109.

\section{Opracowania i artykuły:}

Hubczak M., Spomyny pro naszoho „Sokoła”, [w:] Sokił-Batko. Sportywno-Ruchankowe Towarystwo u Lwowi. Almanach 1894-1994, Lwiw 1996.

Mirkiewicz A., Zarys dziejów sokolstwa słowiańskiego (1862-1939), Rzeszów 2014.

Snopko J., Polskie Towarzystwo Gimnastyczne „Sokół” w Galicji 1867-1914, Białystok 1997.

Śmiechowski K., $Z$ „Sokiłem” w tle. Powstanie i rozwój ukraińskich organizacji gimnastyczno-pożarniczych „Sicz” (1900-1914), „Prace Historyczno-Archiwalne”, t. XXXII, 2020.

Poradnyk dla pożarno-ruchankowych towarystw „Sokił”, zładyła na pidstawi praci Semena Horuka „Na sokołynych kryłach” orh. sekcija „Sokiła-Bat’ka”, Lwiw 1926.

Żarski E., Osnowy Sokilstwa, Lwiw 1937.

\section{Wydawnictwa periodyczne:}

Sokilśkyj Kałendarec 1938, Lwiw 1937.

„Sokilśki Wisty”, nr 1, styczeń-luty 1933.

„Ukrajinśkyj Sokił”, Czasopys Sojuzu Ukrajinśkoho Sokilstwa za Kordonom, nr 4-5, kwiecień-maj 1935.

„Wisty z Zaporoża”, nr 18, [w:] „Narodne Słowo”, nr 361, 12 maja 1910.

„Wisty z Zaporoża”, nr 80, 30 kwietnia 1913. 


\section{Abstract}

\section{Ideological Foundation of the Ukrainian Society "Sokił" (1894-1914), part I Purpose, Duties, Commandments}

Founded in 1894, the Ukrainian Gymnastic-Firefighting Society "Sokił" [Falcon] did not immediately gain the popularity that the organization's leaders wanted. Initially, the society gained recognition only in the academic circles. Only when the organizational development gained particular momentum in the first decade of the $20^{\text {th }}$ century, covering large areas of Galicia and overcoming the bumpy road of internal formation - was it possible to reach the lowest strata of society with its message, and thus gaining the expected authority.

The time has shown that the popularity of Sokił resulted not so much from the fact that it was a gymnastics and firefighting organization, but primarily because it grew into a thriving institution of Ukrainian national life. Under the banner of gymnastics and firefighting, the Ukrainian Sokił began a wide-ranging, multidirectional activity that manifested patriotism and national traditions and concealed deeper goals of national independence.

From the very beginning, the Ukrainian Gymnastic Society Sokił was supposed to be a democratic organization. It was based on a statute, with the general assembly as the highest authority. However, while the statute, which underwent several modifications in the course of organizational development, was given its due place in the publications on the founding and development of the society, all the studies on Sokit, so far, have not devoted their full attention to the systemic and ideological aspect of the society. These aspects served as a doctrinal strengthening of the developed: laws, norms, regulations, duties, membership rules, ceremonials, Sokił uniform, banner, anthem, hierarchical distinctions, organizational badges and propaganda slogans.

As the organization developed and subsequent branches emerged, the Lviv headquarters of Sokił-Batko developed a number of template documents, so that their values would be the same and could be shared with the new societies, which also guaranteed a uniform internal structure to all nests scattered throughout Galicia. The drafting of the documents was entrusted to special committees. And although the Sokił branches differed in the degree to which their organizational structure was developed, thanks to the same theoretical foundations, from a structural point of view they showed homogeneity and integrity.

Therefore, in the presentation of a series of articles on the history of this Ukrainian society, it was deemed appropriate to highlight this little-known and overlooked fragment of the society's activity, which undoubtedly, in some way, complements the overall research subject. However, due to the abundance of material, presenting it in one part would have exceeded the periodical's set volume, so it was only natural to divide it and present it in several parts, and the part: Purpose, Duties, Commandments is the first of them.

\section{Keywords:}

Ukrainian gymnastic and firefighting organization „Falcon”, „Sokil”, Sokił, Ukrainian Sport Association, Sportywno-Ruchankowe Towarystwo Sokil u Lwowi. 